\title{
Reciprocal Dumping under Antidumping Enforcement
}

\author{
Nilanjan Banik ${ }^{*}$ and John Gilbert ${ }^{* *}$
}

\begin{abstract}
In a dynamic extension of the reciprocal dumping approach, oligopolistic firms producing imperfect substitutes use the carrot and stick strategy to enforce cooperative behavior. When dumping occurs, firms lobby for tariffs as punishment. After a finite punishment period, the non-dumping equilibrium is restored. Conditions are derived on the degrees of substitutability and observability that allow non-dumping under an infinite horizon. The model suggests the degree of substitutability between goods and the market interest rate, affect the likelihood of dumping.
\end{abstract}

Keywords: dumping, tariffs, lobbying, carrot and stick strategy

\section{INTRODUCTION}

According to the WTO Annual Report, antidumping duties now have the dubious distinction of being the most widely used non-tariff barrier (NTB). These duties are product specific or source specific tariffs, imposed on 'dumped' imports that are causing harm to domestic industry. Under WTO Article VI, a country may impose antidumping duties if the difference between the export price and normal value (the price of the good

Submission Date: 2/3/2006 Acceptance Date: 5/15/2006

* Corresponding Author: Assistant Professor, Center for Advanced Financial Studies Institute for Financial Management and Research, Chennai, Tamil Nadu, India 60034, Ph: +91-9840561339, E-mail: nil@ifmr.ac.in

${ }^{* *}$ Assistant Professor, Department of Economics, Utah State University, USA 
in the domestic market of the exporting country) is greater than two percent and if the dumped volume exceeds three percent of total imports.

The main rationale behind the antidumping agreement (codified during the Tokyo Round of GATT negotiations in the 1970s) was to stop 'predatory' pricing. However, economists have long found the economic argument for international predation unconvincing. Haberler (1937) regarded dumping as seldom used as an oligopolistic tactic to eliminate competition, and Lloyd (1977) claims that prior to the early 1970 s there were very few instances of predatory dumping. Early work instead considered dumping as resulting from price discrimination across national markets (Viner, 1923). Ethier (1982) characterizes dumping as arising from an inflexible labor market, where there is a search cost associated with finding skilled workers. In the event of a recession, firms prefer dumping products at less than marginal cost to laying off their skilled workers or shrinking their production line. Davies and McGuinness (1982) suggest three primary reasons why any firm would choose to follow a dumping strategy: (i) to deter rival entry, (ii) to maximize firm revenue (without regard for profits) and (iii) to hedge against future uncertainties. Brander and Krugman (1983) by contrast envisage dumping more as a 'tit for tat' strategy followed by rival oligopolistic firms in different national markets, demonstrating that oligopolistic interaction between firms can cause trade in the absence of the usual motivations. More recently, Ethier and Fischer (1987), Messerlin (1989), Finger (1993), Prusa (1996), Clark (1999), and Knetter and Prusa (2000) have focused on the NTB aspect of dumping. These works consider antidumping measures as practiced by the European Union (EU), the US, and the Organization of Economic Cooperation and Development (OECD) countries, as attempts to restrict market access to exports originating from other countries. There now seems to be a growing consensus that antidumping duties are used primarily as a mechanism of protectionism.

The literature mentions two principal ways in which the domestic firm can make its government impose a tariff. First, when the domestic firm strategically alters its behavior (trying to make the foreign firm deviate) and thereby influence antidumping outcomes in the second stage of the game. Ethier and Fischer (1987), Fischer (1992) and Reitzes (1993) mention this 'behavioral' aspect of the domestic firm. Second is by mounting political pressure. For instance, Moore (1992, 1996), DeVault (1993), and Hansen and Prusa $(1996,1997)$ have shown that industries with production facilities in the districts of oversight members fare better in terms of getting antidumping protection. 
What has not been examined is how a strategy of punishment might be used to enforce a cooperative equilibrium in a reciprocal dumping framework.

In this paper we consider a simplified two country model along the lines of Brander and Krugman (1983). In the model we have two symmetric rival national firms engaged in Cournot competition. In the single or finite period version of this game, the Nash equilibrium outcome is reciprocal dumping. Our objective is to show conditions under which the 'stick' of antidumping duties could sustain a collusive equilibrium when we have an infinite time horizon. Our basic story is as follows. The firms repeatedly interact, fully aware of each other's choice in any given period. In any period either firm may choose to cooperate (collude) or compete, but the consequences of deviating from a collusive agreement differ for each firm. We assume that a domestic firm will be able to obtain temporary antidumping protection in the event of a price fall (foreign deviation), provided that it has not itself expanded output. The foreign firm may obtain higher profits from deviating in any period safe in the knowledge that home will not increase output, but must temporarily suffer the consequences of the antidumping duty in subsequent periods. We derive the conditions on the degree of substitutability that allow firms to operate without dumping.

\section{THE MODEL}

We begin with a variant of the basic reciprocal dumping model of Brander and Krugman (1983). This is a simple model of competition between a domestic firm (1) and a foreign firm (2) selling in each others' markets. Following Eaton and Grossman (1986) and Dixit (1988), we use linear inverse demand functions for the domestic and foreign firms for simplicity. Throughout the analysis we will assume that firms compete in quantities. ${ }^{1}$ In any given period the inverse demand functions in the domestic market are:

$$
\begin{aligned}
& p_{1}=a_{1}-b_{1} q_{1}-k q_{2} \\
& p_{2}=a_{2}-k q_{1}-b_{2} q_{2}
\end{aligned}
$$

where $p_{i}$ denotes the price and $q_{i}$ the quantity for the domestic and the foreign firm,

\footnotetext{
${ }^{1}$ This assumption is motivated by findings of Singh and Vibes (1984) which surmise that in a game involving differentiated duopoly when firms have options to choose between Cournot and Bertrand strategies, the Cournot strategy is preferred.
} 
respectively, in the domestic market. $k$ denotes the degree of product substitutability between the two firms. ${ }^{2}$

Assuming symmetry, the same conditions hold in the foreign market. Hence we can continue the analysis in terms of the domestic market alone. Individual firm profit functions in the domestic market are:

$\pi_{1}=\left(a_{1}-b_{1} q_{1}-k q_{2}-c_{1}\right) q_{1}$
$\pi_{2}=\left(a_{2}-b_{2} q_{2}-k q_{1}-c_{2}\right) q_{2}$

where $c_{i}$ is the (constant) marginal cost.

While in a single period or finite period version of this game the Nash equilibrium solution will be for each firm to dump, let us suppose that in the period under consideration the firms act collusively to maximize joint profit. In the next section we address how this equilibrium could be sustained over time. In a duopolistic setup with firms facing downward sloping demand schedules, collusive output results in higher joint profit relative to the Cournot solution. The quantities produced under the agreement are:

$$
\begin{aligned}
& q_{1}^{c}=\frac{b_{2}\left(a_{1}-c_{1}\right)-k\left(a_{2}-c_{2}\right)}{2 b_{1} b_{2}-k^{2}} \\
& q_{2}^{c}=\frac{b_{1}\left(a_{2}-c_{2}\right)-k\left(a_{1}-c_{1}\right)}{2 b_{1} b_{2}-k^{2}}
\end{aligned}
$$

Since both $q_{i}^{c}>0$ and $b_{1} b_{2}-k^{2}>0$, we know that both $b_{2}\left(a_{1}-c_{1}\right)-k\left(a_{2}-c_{2}\right)>0$ and $b_{1}\left(a_{2}-c_{2}\right)-k\left(a_{1}-c_{1}\right)>0$. Under the assumption of symmetry, an agreement in both countries results in the same total profit for each firm.

As noted above, such collusion is not a single period Nash equilibrium and thus does not constitute a solution to the game in a single period. To see this, suppose that the foreign firm deviates from cooperation in some period. Assuming Cournot behavior, if it deviates optimally, it takes the cooperative output of the domestic firm as given and maximizes its own profits. The optimum output level for the foreign firm is thus:

\footnotetext{
${ }^{2}$ A convenient property of this functional form is that conjecture effects in the firms' first order conditions are constant. We further assume that the own price effect is greater than the cross price effect $\left(b_{i}>k\right)$, implying that the products are imperfect substitutes.
} 
$q_{2}^{d}=\frac{\left(a_{2}-c_{2}\right)\left(2 b_{1} b_{2}-k^{2}\right)-k b_{2}\left(a_{1}-c_{1}\right)}{4 b_{2}\left(b_{1} b_{2}-k^{2}\right)}$

Now, $q_{2}^{d}-q_{2}^{c}>0$ since $k$ and $b_{1} b_{2}-k^{2}>0$ and $b_{1}\left(a_{2}-c_{2}\right)-k\left(a_{1}-c_{1}\right)>0$.

In other words, the foreign firm would produce more than under collusion. Since output is larger, with the marginal cost of production remaining unchanged, the foreign firm's profits rise. Hence, considering any single period, the foreign firm has an incentive to deviate from the agreement. Of course, the same argument could be made with respect to the domestic firm, and indeed this is just one way of thinking about the reciprocal dumping outcome. Deviation by the foreign firm constitutes dumping, since the price being charged in the domestic market is lower than the price of the same product in the foreign market.

Now consider the role of antidumping duties and the repeated nature of the interaction. Suppose following a period of collusion that the foreign firm does choose to deviate in a given period. Suppose that antidumping duties can be imposed in response in the next period, but only if the domestic firm has not increased its output in the period in which the foreign firm deviated. ${ }^{3}$ The domestic firm thus does not respond for one period, and the foreign firm makes higher profits for that period, as established above. The domestic firm realizes lower profits relative to cooperation.

Now consider the response. In the next period the home firm is assumed to successfully lobby for a tariff of $\tau$ per unit. Hence, in this period the profit function of the foreign firm becomes:

$$
\pi_{2}=\left(a_{2}-b_{2} q_{2}-k q_{1}-c_{2}-\tau\right) q_{2}
$$

The reaction functions of the two firms are:

$$
\begin{aligned}
& -b_{1} q_{1}+\left(a_{1}-b_{1} q_{1}-k q_{2}-c_{1}\right)=0 \\
& -b_{2} q_{2}+\left(a_{2}-k q_{1}-b_{2} q_{2}-c_{2}-\tau\right)=0
\end{aligned}
$$

Solving for the optimum values for $q_{1}$ and $q_{2}$ yields:

\footnotetext{
${ }^{3}$ Our rationale for this assumption is that the domestic firm must prove material injury, and that this would be difficult if it has expanded production.
} 


$$
\begin{aligned}
q_{1}^{\tau} & =\frac{2 b_{2}\left(a_{1}-c_{1}\right)-k\left(a_{2}-c_{2}-\tau\right)}{4 b_{1} b_{2}-k^{2}} \\
q_{2}^{\tau} & =\frac{2 b_{1}\left(a_{2}-c_{2}-\tau\right)-k\left(a_{1}-c_{1}\right)}{4 b_{1} b_{2}-k^{2}}
\end{aligned}
$$

The equilibrium output produced is increasing in duty for the domestic firm and decreasing in tariff for the foreign firm, as we expect. Also, the amount of output the domestic firm sells in the presence of tariffs is greater than the amount it sells in absence of tariffs whereas the opposite holds true for the foreign firm, i.e., $q_{2}^{\tau}<q_{i}^{c}<q_{1}^{\tau}$.

The domestic firm gains the most when the antidumping duties imposed are prohibitive, and we assume for simplicity that this is the case. ${ }^{4}$ Since a prohibitive tariff ensures that the foreign firm earns zero profits in the domestic market during punishment we can write:

$$
\tau^{*}=a_{2}-b_{2} q_{2}^{\tau}-k q_{1}^{\tau}-c_{2}
$$

Making use of (6) and (7) then yields:

$$
\tau^{*}=\frac{\left(a_{1}-c_{1}\right) k}{2 b_{1}}+\left(a_{2}-c_{2}\right)
$$

which simply implies that when a prohibitive tariff has been imposed, the domestic firm produces the monopoly level of output and the foreign firm produces nothing for sale in the domestic market, i.e., $q_{1}^{\tau}\left(\tau^{*}\right)=\left(a_{1}-c_{1}\right) / 2 b_{1}$ and $q_{2}^{\tau}\left(\tau^{*}\right)=0$.

Since $q_{1}^{\tau}\left(\tau^{*}\right)>q_{1}^{c}$ and $q_{2}^{\tau}\left(\tau^{*}\right)<q_{2}^{c}$, profits for the domestic firm when the government imposes antidumping duties is greater than the profit it earns during collusion.

\footnotetext{
${ }^{4}$ The basic results hold when considering a less extreme response (see Appendix A).
} 


\section{A DYNAMIC CONDITION FOR DUMPING}

Now consider the full dynamic game. Consider a point where both firms are colluding. The foreign firm knows that the domestic firm will not respond to dumping by expanding output, since by assumption the antidumping duties could not then be enacted. The foreign firm must therefore weigh the higher profits it can make in the one period it can dump without response against the lower profits it makes once the punishment is in place. Suppose that punishment lasts for one period. ${ }^{5}$ Staring from cooperation, given the knowledge of the strategy involved and assuming the rate of discount to be $\delta$ in each stage of the game, the condition under which the foreign firm will not deviate (dump) is:

$$
\sum_{t=0}^{\infty} \delta_{t} \pi_{i}^{c}>\pi_{i}^{d}+\delta \pi_{i}^{p}+\sum_{t=2}^{\infty} \delta_{t} \pi_{i}^{c}
$$

where $\delta$ reflects the rate of discount and $\eta_{2}$ represents the price elasticity of demand for the foreign firm. Hence, $\pi_{i}^{c}(1+\delta)>\pi_{i}^{d}+\delta \pi_{i}^{P}$. The foreign firm earns zero profit in the punishment phase. Hence, $\pi_{i}^{p}=0$ or $\delta \pi_{2}^{c}\left(q_{2} / p_{2}\right)<1 / \eta_{2}\left(q_{2}^{d}-q_{2}^{c}\right)^{2}$ where $q_{2}^{d}$ and $q_{2}^{c}$ represent output produced by the foreign firm under the punishment phase and under the cooperative phase, respectively (see Appendix B).

We can draw two conclusions:

Proposition 1: For a given difference between monopoly output, $q_{2}^{d}$, and duopoly output $q_{2}^{c}$, the foreign firm is more likely to deviate if the market rate of interest is high. A higher interest rate implies a lower present discounted value of the income stream of profit, making dumping more attractive.

Proposition 2: The reaction function of the foreign firm, $R_{2}\left(\left(q_{1}^{c}, \eta_{2}\right) ; q_{2}^{d}\right)$, is decreasing in $\eta_{2}$. Hence, the foreign firm is more likely to deviate if the product is price inelastic.

Proof: See Appendix C.

\footnotetext{
${ }^{5}$ Antidumping duties cannot remain in place indefinitely. The 'Sunset Clause' in Article 11.3 of the antidumping agreement states, "definitive antidumping duty shall be terminated on a date not later than five years from its imposition". Moreover, the government can revoke antidumping duties before the five year period, if it feels there is no further instances of material injury resulting from dumping (Article 11.2 of the antidumping agreement).
} 


\section{CONCLUSION}

The paper considers the conditions under which a foreign firm will dump, given the presence of punishment (in the form of antidumping duties) and a carrot and stick strategy. Oligopolists are assumed to use the carrot and stick strategy to enforce cooperative (non-dumping) behavior. When the foreign firm dumps in the domestic market, the domestic firm is assumed to lobby its government for a prohibitive tariff as punishment. After some period of punishment, the firms return to the non-dumping equilibrium. Hence, this paper characterizes antidumping duties as a mechanism with which to enforce a collusive outcome in a dynamic extension of the reciprocal dumping approach. The model suggests that the changes in the market rate of interest and the degree of substitutability between goods, affect the likelihood of dumping.

Under WTO rules, a foreign firm is considered to dump if the price difference between the export price (cost insurance freight price) and normal value (price of the good in the domestic market of the exporting country) is greater than two percent. This definition therefore cannot identify the reasons for dumping. In case of predatory pricing, the foreign firm makes some losses in the initial stage (selling at a price below marginal cost). In our model we have assumed that the foreign firm maximizes profit and hence is not dumping from the predatory perspective. This dumping behavior of the foreign firm is welfare augmenting for the domestic economy because it is not going to raise price in the future.

An extension of this model would involve imperfect information on the part of the government and continuous lobbying by the domestic firm for a protective tariff. Given the information asymmetry, one could ask how much the domestic firm would spend to 'foo' the government, or how much the government would spend to detect dumping by foreign firms.

\section{REFERENCES}

Brander, J. and Krugman, P., 1983, “A Reciprocal Dumping Model of International Trade," Journal of International Economics, 15, 313-21.

Clark, D. P., 1999, "Non-Tariff Barriers and US Imports from Western Hemisphere Developing Countries," Journal of Social and Economic Studies, 48, 137-52. 
Davies, S. W. and McGuinness, A. J., 1982, 'Dumping At Less Than Marginal Cost,' Journal of International Economics, 12, 169-82.

DeVault, J. M., 1993, "Economics and the International Trade Commission," Southern Economic Journal, 60, 463-78.

Dixit, A. K., 1988, "Anti-Dumping and Countervailing Duties Under Oligopoly," European Economic Review, 32, 55-68.

Eaton, J. and Grossman, G. M., 1986, "Optimal Trade and Industrial Policy for the US Automobile Industrial Policy Under Oligopoly," Quarterly Journal of Economics, $100,383-406$.

Ethier, W. J., 1982, “Dumping,” Journal of Political Economy, 90, 481-506.

Eithier, W. J. and Fischer, R. D., 1987, "The New Protectionism," Journal of International Economic Integration, 2, 1-11.

Finger, J. M. (ed.), 1993, Antidumping: How its Works and Who Gets Hurt, The University of Michigan Press, Ann Arbor.

Fischer, D. R., 1992, "Endogenous Probability of Protection and Firm Behavior," Journal of International Economics, 32, 149-63.

Haberler, G. V., 1937, The Theory of International Trade with its Application to Commercial Policy, Macmillan, New York.

Hansen, L. W. and Prusa, T. J., 1996, "Cumulation and ITC Decision Making: The Sum of the Parts is Greater than the Whole," Economic Enquiry, 34, 746-69.

Hansen, L. W. and Prusa, T. J., 1997, "The Economics and Politics of Trade Policy: An Empirical Analysis of ITC Decision Making," Review of International Economics, 5, 230-45.

Knetter, M. M. and Prusa, T. J., 2000, "Macroeconomic Factors and Antidumping Filings: Evidence from Four Countries," National Bureau of Economic Research, Working Paper W8010.

Lloyd, P. J., 1977, “Antidumping Actions and the GATT System," Thames Essay, 9. Trade Policy Resource Centre, London.

Messerlin, P., 1989, "GATT Inconsistent Outcomes of GATT Consistent Laws: The Long Term Evolution of the EC Antidumping Laws," Mimeo.

Moore, M. O., 1992, "Rules or Politics? An Empirical Analysis of ITC Antidumping Decisions," Economic Enquiry, 30, 449-66.

Moore, M. O., 1996, "The Rise and Fall of Big Steel's Influence on U.S. Trade Policy," in Krueger, A. O. (ed.), The Political Economy of Trade Protection, University of Chicago Press. 
Prusa, T., 1996, “The Trade Effects of U.S. Antidumping Actions," National Bureau of Economic Research. Working Paper W5440.

Reitzes, D. J., 1993, “Antidumping Policy,” International Economic Review, 34, 745-63.

Singh, N. and Vibes, X., 1984, "Price and Quantity Competition in a Differentiated Duopoly," The Rand Journal of Economics, 15, 546-554.

Viner, J., 1923, “Dumping: A Problem in International Trade,” University of Chicago Press. 


\section{Appendix A: Endogenizing the Antidumping Rate}

Suppose that the tariff is not simply granted but rather must be lobbied for by the domestic firm, at a cost. Suppose the profit functions of the two firms are:

$$
\begin{aligned}
& \pi_{1}=\left(a_{1}-b_{1} q_{1}-k q_{2}-c_{1}\right) q_{1}-\tau^{\alpha} \\
& \pi_{2}=\left(a_{2}-b_{2} q_{2}-k q_{1}-c_{2}-\tau\right) q_{2}
\end{aligned}
$$

where $\tau^{\alpha}$ is the lobbying cost of the tariff and alpha is a positive scalar with value greater than one to ensure convexity.

There are three variables, $q_{1}, q_{2}$ and $\tau$. In stage 1 we solve for optimum $q_{2}$ from the foreign firm's reaction function and substitute into equation (1), yielding:

$$
\left(a_{1}-b_{1} q_{1}+\frac{k\left(\tau-a_{2}+k q_{1}+c_{2}\right)}{2 b_{2}}-c_{1}\right) q_{1}-\tau^{2}
$$

Next we differentiate equation (3) with respect to $q_{1}$ and $\tau$ solve, which yields:

$$
\begin{aligned}
& q_{1}=\frac{4 b_{2} d\left\{k\left(a_{2}-c_{2}\right)-2 b_{2}\left(a_{1}-c_{1}\right)\right\}}{8 b_{2}\left(k^{2}-2 b_{1} b_{2}\right)+k^{2}} \\
& \tau=\frac{k\left\{k\left(a_{2}-c_{2}\right)-2 b_{2}\left(a_{1}-c_{1}\right)\right\}}{8 b_{2}\left(k^{2}-2 b_{1} b_{2}\right)+k^{2}}
\end{aligned}
$$

The endogenized tariff rate is less than the prohibitive tariff rate since:

$$
\tau^{*}-\tau=\frac{1}{2 b_{1}} k\left(a_{1}-c_{1}\right)+\left(a_{2}-c_{2}\right)\left[\frac{2 b_{1} k-8 b_{2}\left(2 b_{1} b_{2}-k^{2}\right)}{8 b_{2}\left(k^{2}-2 b_{1} b_{2}\right)+k^{2}}\right]>0
$$




\section{Appendix B: Deriving the Condition for Deviation}

The profit functions for the foreign firm under collusion and dumping, respectively, are:

$$
\begin{aligned}
& \pi_{2}^{c}=\left(a_{2}-b_{2} q_{2}^{c}-k q_{1}^{c}-c_{2}\right) q_{2}^{c} \\
& \pi_{2}^{d}=\left(a_{2}-b_{2} q_{2}^{d}-k q_{1}^{c}-c_{2}\right) q_{2}^{d}
\end{aligned}
$$

Therefore:

$\pi_{2}^{d}-\pi_{2}^{c}=\left(q_{2}^{d}-q_{2}^{c}\right)\left(a_{2}-c_{2}-k q_{1}^{c}-b_{2}\left(q_{2}^{d}+q_{2}^{c}\right)\right)$

Now, $\left(q_{2}^{d}+q_{2}^{c}\right)=\frac{\left(a_{2}-c_{2}\right)\left(4 b_{1} b_{2}-k^{2}\right)-3 k b_{2}\left(a_{1}-c_{1}\right)}{4 b_{2}\left(b_{1} b_{2}-k^{2}\right)}$

Substituting in (B1) yields:

$$
\pi_{2}^{d}-\pi_{2}^{c}=\left(q_{2}^{d}-q_{2}^{c}\right)\left(a_{2}-c_{2}-k q_{1}^{c}-b_{2}\left\{\frac{\left(a_{2}-c_{2}\right)\left(4 b_{1} b_{2}-k^{2}\right)-3 k b_{2}\left(a_{1}-c_{1}\right)}{4 b_{2}\left(b_{1} b_{2}-k^{2}\right)}\right\}\right)
$$

Which reduces to simply:

$$
\pi_{2}^{d}-\pi_{2}^{c}=b_{2}\left(q_{2}^{d}-q_{2}^{c}\right)^{2}
$$

From the condition of deviation,

$$
\begin{aligned}
& \pi_{2}^{c}(1+\delta)>\pi_{2}^{d}+\delta \pi_{2}^{P} \\
& \delta \pi_{2}^{c}>\pi_{2}^{d}-\pi_{2}^{c}
\end{aligned}
$$


Using (B1) and (B2) we obtain:

$$
\begin{aligned}
& \delta \pi_{2}^{c}>b_{2}\left(q_{2}^{d}-q_{2}^{c}\right)^{2} \\
& \delta \pi_{2}^{c}\left(q_{2} / p_{2}\right)<1 / \eta_{2}\left(q_{2}^{d}-q_{2}^{c}\right)^{2}
\end{aligned}
$$




\section{Appendix C: Proof of Proposition 2}

The profit function of the foreign firm when it deviates is:

$\pi_{2}^{d}=\left(a_{2}-b_{2} q_{2}^{d}-k q_{1}^{c}-c_{2}\right) q_{2}^{d}$

For a given level of domestic firm's output $\left(q_{1}^{c}\right)$, a negative $d \pi\left(R_{2}\left(q_{1}^{c}, \eta_{2}\right) ; q_{2}^{d}\right) / d \eta_{2}$ indicates that the profit of the foreign firm increases with a more inelastic demand.

From equation (C1):

$\pi_{2}^{d}=\left(a_{2}-\left(p_{2} / \eta_{2}\right)-k q_{1}^{c}-c_{2}\right) q_{2}^{d}$

and:

$\partial \pi\left(R_{2}\left(q_{1}^{c}, \eta_{2}\right) ; q_{2}^{d}\right) / \partial \eta_{2}=\partial\left(-p_{2} q_{2}^{d} / \eta_{2}\right) / \partial \eta_{2}$

Now, $q_{2}^{d}=\frac{\left(2 b_{1} b_{2}-k^{2}\right)\left(a_{2}-c_{2}\right)-k b_{2}\left(a_{1}-c_{1}\right)}{4 b_{2}\left(b_{1} b_{2}-k^{2}\right)}$.

Therefore $-p_{2} q_{2}^{d} / \eta_{2}$ can be written as:

$$
\frac{-\left(p_{2} / q_{2}\right)\left(1 / \eta_{2}\right)\left[\left(2 b_{1}\left(a_{2}-c_{2}\right)-k\left(a_{1}-c_{1}\right)\right]\right.}{4\left(1 / q_{2}\right)\left(b_{1}\left(p_{2} / q_{2}\right)\left(1 / \eta_{2}\right)-k^{2}\right)}+\frac{k^{2}\left(a_{2}-c_{2}\right)}{4\left(1 / q_{2}\right)\left(b_{1}\left(p_{2} / q_{2}\right)\left(1 / \eta_{2}\right)-k^{2}\right)}
$$

Define $\vartheta \equiv-\frac{\left(p_{2} / q_{2}\right)\left(1 / \eta_{2}\right)\left[\left(2 b_{1}\left(a_{2}-c_{2}\right)-k\left(a_{1}-c_{1}\right)\right]\right.}{4\left(1 / q_{2}\right)\left(b_{1}\left(p_{2} / q_{2}\right)\left(1 / \eta_{2}\right)-k^{2}\right)}$

and: 


$$
\psi \equiv \frac{k^{2}\left(a_{2}-c_{2}\right)}{4\left(1 / q_{2}\right)\left(b_{1}\left(p_{2} / q_{2}\right)\left(1 / \eta_{2}\right)-k^{2}\right)} .
$$

Differentiating $\vartheta$ with respect to $\eta_{2}$ :

$$
\frac{\partial \vartheta}{\partial \eta_{2}}=-4 k^{2}\left(p_{2} / \eta_{2}\right) \frac{\left[\left(2 b_{1}\left(a_{2}-c_{2}\right)-k\left(a_{1}-c_{1}\right)\right]\right.}{\left\{4\left(b_{1}\left(p_{2} / q_{2}\right)\left(1 / \eta_{2}\right)-k^{2}\right)\right\}^{2}}<0
$$

Differentiating $\psi$ with respect to $\eta_{2}$ :

$$
\frac{\partial \psi}{\partial \eta_{2}}=\frac{\partial \psi}{\partial \eta_{2}}=\frac{4 k^{2}\left(p_{2} / \eta_{2}^{2}\right) b_{1}\left(a_{2}-c_{2}\right)}{\left\{4\left(b_{1}\left(p_{2} / q_{2}\right)\left(1 / \eta_{2}\right)-k^{2}\right)\right\}^{2}}>0
$$

Now, $\partial \pi\left(R_{2}\left(q_{1}^{c}, \eta_{2}\right) ; q_{2}^{d}\right) / \partial \eta_{2}=\frac{\partial \vartheta}{\partial \eta_{2}}+\frac{\partial \psi}{\partial \eta_{2}}$

Comparing equation (C3) and (C4), we note that $2 b_{1}\left(a_{2}-c_{2}\right)-k\left(a_{1}-c_{1}\right)>b_{1}\left(a_{2}-c_{2}\right)$.

Hence:

$$
\partial \pi\left(R_{2}\left(q_{2}^{d}, \eta_{2}\right) ; q_{1}^{c}\right) / \partial \eta_{2}<0
$$

